\title{
INTERNATIONAL INVESTMENT LAW AND UNIVERSALITY: HISTORIES OF SHAPE-SHIFTING
}

\author{
Kate Miles
}

\begin{abstract}
The following article was first presented as an address at the annual conference of the Cambridge Journal of International and Comparative Law on 10 May 2014. It concerns themes developed in detail in Dr Miles' book, The Origins of International Investment Law: Empire, Environment and the Safeguarding of Capital, published by Cambridge University Press in 2013.
\end{abstract}

The theme for this year's conference, universality and the cosmopolitan nature of international law, involves questions with which the international community has been engaged for some time. Indeed, the tendency to invoke our own tradition, whatever that may be, as representative of the universal, has a long history. In highlighting this propensity, scholars have drawn attention to individual historical examples, from the Roman Empire onwards and, in particular, have articulated the invocation of universality in the translation of European tradition into international law. ${ }^{1}$ It is now, of course, well recognised that the universal application of rules of international law was primarily a result of the commercial and political expansionism that occurred during imperial activity in the nineteenth century. ${ }^{2}$ Additionally, a further period of 'universalisation' of international law was experienced through decolonisation in the mid-twentieth century. ${ }^{3}$ The enduring significance of this for the nature of international law, however, is the subject of divergent opinion; as is the purpose, meaning, and

\footnotetext{
Fellow and Lecturer in Law, Gonville and Caius College, University of Cambridge.

1 Martti Koskenniemi, 'International Law in Europe: Between Tradition and Renewal' (2005) 16 EJIL 113, 114. In particular, Koskenniemi refers to Roman law, Christianity, the 'humanity' of the Enlightenment, Vitoria, Grotius, Weber, science and capitalism, and modernity and globalisation; see also, for example, Eve Darian-Smith and Peter Fitzpatrick, Laws of the Postcolonial: Law, Meaning and Violence (1999).

2 Koskenniemi, above n 1; Antony Anghie, 'Finding the Peripheries: Sovereignty and Colonialism in Nineteenth-Century International Law' (1999) 40 Harv IJL 1; David Kennedy, 'International Law and the Nineteenth Century: History of an Illusion' (1997) 17 Quinnipiac LR 99.

3 Sundhya Pahuja, Decolonising International Law: Development, Economic Growth and the Politics of Universality (2011) 29-30.
} 
implications of persistent appeals to the universal in international law. ${ }^{4}$ What is evident from contemporary discourse, to which this conference contributes, is that such issues not only remain of importance and require further excavation, but also still generate controversy and strongly-held views.

In the context of international investment law, the debate surrounding universality has its own layer of significance. Advocates of traditional modes of high-level investment protection and international arbitration have long appealed to the universality, neutrality, and objectivity of these rules and their dispute settlement fora. ${ }^{5}$ Such traits are often held up as evidencing the legitimacy of investor-state arbitration as a system and as a means by which disputes can be divorced from what is referred to as 'the politicised environment' of the host state. And, most recently, such appeals to universality have found form in associations with global administrative law, in which investor-state arbitration has been framed as the very embodiment of the rule of law. ${ }^{6}$

Ostensibly, there should be little concern in such a proposition. Indeed, who could object to the 'neutral', the 'universal', the 'objective'? And that is, perhaps,

4 Ibid; Pierre-Marie Dupuy, 'Some Reflections on Contemporary International Law and the Appeal to Universal Values: A Response to Martti Koskenniemi' (2005) 16 EJIL 131.

5 See, for example, Jan Paulsson, 'Universal Arbitration: What We Gain, What We Lose' (2013) 79 Arbitration 184; I F I Shihata, Towards a Greater Depoliticization of Investment Disputes: The Roles of ICSID and MIGA (ICSID, 1993); J W Yackee, 'Pacta Sunt Servanda and State Promises to Foreign Investors Before Bilateral Investment Treaties: Myth and Reality' (2009) 32 Fordham ILJ 1550; see the discussion in Andrew Newcombe \& Lluís Paradell, Law and Practice of Investment Treaties: Standards of Treatment (2009) 27-9; see also the discussion in Serg Puig, 'No Right Without a Remedy: Foundations of Investor-State Arbitration' in Zachary Douglas, Joost Pauwleyn \& Jorge E Viñuales (eds), The Foundations of International Investment Law: Bringing Practice into Theory (2014) 235, 243-6; see also the views in Todd Weiler \& Thomas W Wälde, 'Investment Arbitration under the Energy Charter Treaty in the Light of New NAFTA Precedents: Towards a Global Code of Conduct for Economic Regulation' (2004) 1 TDM 1.

6 See for example, Weiler \& Wälde, above n 5; Stephan W. Schill, 'Fair and Equitable Treatment under Investment Treaties as an Embodiment of the Rule of Law' (2006) IILJ Working Paper 2006/6 (Global Administrative Law Series) <http://iilj.org/publications/documents/2006-6-GALSchill-web.pdf> [accessed 25 August 2014]; Benedict Kingsbury \& Stephan Schill, 'Investor-State Arbitration as Governance: Fair and Equitable Treatment, Proportionality and the Emerging Global Administrative Law' (2009) IILJ Working Paper 2009/6 (Global Administrative Law Series) <http://www.iilj.org/publications/documents/2009-6.KingsburySchill.pdf> [accessed 25 August 2014]; Daniel Kalderimis, 'Investment Treaty Arbitration as Global Administrative Law: What This Might Mean in Practice', in Chester Brown \& Kate Miles (eds), Evolution in Investment Treaty Law and Arbitration (2011) 145; Charles T. Kotuby, "Other International Obligations" as the Applicable Law in Investment Arbitration' (2011) 14 Int'l Arb LR 162, 164; Andrea Rocha Postiga, 'The Emergence of Global Administrative Law as a Means of Transnational Regulation of Foreign Direct Investment' (2013) 10 Brazilian JIL 171. 
the intent of the invocation. It also constitutes, however, the platform from which the enquiry in this article moves. Rather than taking claims to universality and neutrality in the investment field at face value, it would seem they require a more in-depth evaluation; one that engages with the broader circumstances, their historical context, and the critical legal theory scholarship on universality more generally. Certainly, consideration of postcolonial theory and the history of international investment law can throw a different light on current appeals to the universal and attempts to frame international investment law as global administrative law. With this in mind, then, this article explores both past and present claims to universality and neutrality, the constructed nature of doctrines, the emergence of regimes, and the dynamics of challenge and response visible within international investment law. The thread running through my arguments, linking these components, is that with respect to international investment law, claims to universality are really about claiming legitimacy in the face of challenge.

\section{Revisiting the Emergence of International Law}

It is uncontroversial to point to the European origins of international law. It is more contentious, however, to reflect on the significance of this for international law in the twenty-first century and to draw out the role of colonialism in shaping its doctrines. ${ }^{7}$ This territory has been well-traversed by the work of scholars such as Antony Anghie and Lauren Benton, in which that inherent nexus has been fully articulated. ${ }^{8}$ The emergence of international law is depicted as a chaotic process of 'repetitive assertions of power and responses to power' and one in which the engagement of European states with non-European peoples through the prism of colonialism was central, rather than incidental, to the forming of core doctrines of international law. ${ }^{10}$ In particular, Anghie maintains that legal doctrines, such as that of sovereignty, were moulded so as to address the problem of 'civilising the uncivilised world', bringing the non-European 'into the universal civilisation of Europe.'11

\footnotetext{
7 See for example, the arguments put forward in Antony Anghie, 'The Evolution of International Law: Colonial and Postcolonial Realities' (2006) 27 Third World Quarterly 739.

8 Ibid; see also Antony Anghie, Imperialism, Sovereignty and the Making of International Law (2004); see also Lauren Benton, Law and Colonial Cultures: Legal Regimes in World History, 1400-1900 (2002).

9 Benton, above n 8, 10-11.

${ }^{10}$ Anghie, above n 8, 2-8; Anghie, above n 7, 741-2.

${ }^{11}$ Ibid; Anghie, above n 8, 2-8.
} 
It is, of course, somewhat unnecessary to restate that under the doctrine of sovereignty all sovereign states are equal. However, when its nineteenth century conceptual framework is considered, the implicit assumptions set within the doctrine become apparent. ${ }^{12}$ 'Sovereignty' within nineteenth century international law not only denoted sovereign power and governance in the European sense of the word, but was also understood as adherence to a particular form of European civilisation and society. ${ }^{13}$ In the application of the doctrine to non-European societies, such peoples were regarded as not meeting the 'civilisation' and 'society' criteria and were therefore categorised as 'not sovereign. ${ }^{14}$ And, in this way, what Anghie terms a 'dynamic of difference' was enabled, resulting in: ${ }^{15}$

[T] he endless process of creating a gap between two cultures, demarcating one as 'universal' and civilised and the other as 'particular' and uncivilised, and seeking to bridge the gap by developing techniques to normalise the aberrant society.

International law, then, was the tool through which that universal system of demarcation could be established and legitimised, cementing the 'civilised' and 'uncivilised' designations within the law. ${ }^{16}$ Without the legal status of a sovereign entity within a system that had been declared universal, non-European societies were not legally 'visible' on the international stage. It flowed from this that they also did not have the legal capacity to object to their categorisation, nor to its consequences of subjugation and dispossession. ${ }^{17}$

There were, however, inconsistencies in this mode of engagement. At times, the prescribed lack of sovereignty enabled acquisition through conquest and seizure or the expanded doctrine of terra nullius; on other occasions, indigenous

${ }^{12}$ Anghie, above n 7, 745; Martii Koskenniemi, The Gentle Civilizer of Nations: The Rise and Fall of International Law 1870-1960 (2001) 5, 70-5; see the writings discussed in Koskenniemi, such as Henri Bonfils and Paul Fauchille, Manuel de droit international public (2nd edn, 1898) 17-18; see also, for example, the writings of John Westlake, Chapters on the Principles of International Law (1894) 141; see also James Lorimer, The Institutes of the Law of Nations: A Treatise of the Jural Relations of Separate Political Communities (1883).

${ }^{13}$ Anghie, above n 8, 2-8; Anghie, above n 7, 741-2, 745; see the writings at the time of theorists such as Westlake, above $\mathrm{n} 12,141$.

${ }^{14}$ Koskenniemi, above n 12, 70-5; Anghie, above n 7, 741-2, 745.

${ }^{15}$ Anghie, above $\mathrm{n} 8,4$.

${ }^{16}$ Anghie, above n 7, 741-2; Koskenniemi, above n 12, 126-30; Peter Fitzpatrick, 'Terminal Legality: Imperialism and the (De)composition of Law', in Diane Kirby \& Catharine Colebourne (eds), Law, History, Colonialism: The Reach of Empire (2001).

${ }^{17}$ Anghie, above n 7, 745. 
peoples were treated as possessing sovereignty for they entered into treaties ceding sovereignty to the European party. ${ }^{18}$ The seeming contradiction of upholding the legal nature of treaties entered into with rulers, tribes, chiefs, and peoples to whom sovereignty was simultaneously denied posed an obvious problem of logic. ${ }^{19}$ It could, of course, be viewed as a reflection of the realities and limits of empire, in which variegated levels of jurisdiction were asserted, or it could be seen as a disingenuous manipulation of rules to ensure outcomes that serve one set of interests. In any case, what it certainly illustrates is the chaotic, variable, and often improvised nature of international law at the time. ${ }^{20}$ Inconsistencies were accommodated and various forms of jurisdictional pluralism were the norm in the engagement of empire. It was more a fluid and ongoing process of exchanges, shifting shape as circumstances required. ${ }^{21}$

In the positivist account of international law, however, its emergence was painted almost as a serene act of inevitability-the extension of a fully developed, stable, sophisticated and universal legal system to govern international relations across the board. ${ }^{22}$ Again, this particular framing was very much tied in with the 'civilising mission' of the nineteenth century so that not only was the universalising of European law and civilisation taken as self-evident, but the virtue in that mission was as well. ${ }^{23}$ That sense of the self-evident persisted through this constructed fait accompli presentation of European law and civilisation as universally applicable international law. It allowed a wilful closing of the eyes to the problematic aspects of logic, the value-laden and self-serving nature of its principles, the innate linking with the objectives of colonialism, the brutality inflicted, and the reality of an unruly process of engagement through assertion, challenge, and response that was the emergence of international law as a system.

Comprising part of the lineal narrative of the history of international law, it was also the same intellectual approach that enabled the categorisation of gradations of civilisation amongst nations and the bestowing of sovereignty on those that 'progressed' to achieve the requisite standard of civilisation

\footnotetext{
${ }^{18}$ Ibid, 745; Anghie, above n 8, 69-72.

${ }^{19}$ Anghie, above n 8, 69-80.

${ }^{20}$ See the discussion on imperial order and the inconsistent approach to international law and sovereignty in P G McHugh, "A Pretty Gov[ernment]!": The "Confederation of United Tribes" and Britain's Quest for Imperial Order in the New Zealand Islands during the 1830s', in Lauren Benton \& Richard J Ross (eds), Legal Pluralism and Empires, 1500-1850 (2013) 233, 234-6.

${ }^{21}$ Ibid; see generally Lauren Benton, A Search for Sovereignty: Law and Geography in European Empires, 1400-1900 (2009).

${ }^{22}$ Anghie, above n 8, 3-6.

${ }^{23}$ Ibid; Koskenniemi, above n 12, 5, 70-5.
} 
as determined by, and on terms set by, European states. ${ }^{24}$ It was a form of reductionism that simplified and sanitised the realities of universalising international legal rules. And, in the nineteenth century, this allowed the recurrent presentation of an established, complete, and uncontested system of international law even as it was in the midst of a messy and very much contested process of creation. The appeals to the universal nature of those legal rules were part of that assertion of legitimacy in the face of opposition and uncertainty. It is interesting to note that as these historical circumstances have become more widely appreciated, the positivist response has shifted substance but maintained its approach. Smoothing over the uncomfortable, it is not uncommon to find this era and the reality of international law's emergence treated now as simply a matter of historical fact with no further significance. ${ }^{25}$ Amounting to little more than a statement of 'it is what it is', there is an abdication of responsibility and a shrug of indifference embodied within such an approach, whilst, simultaneously, not appearing to endorse the activities of the era.

To say that histories of international law will inevitably reflect the historian is, of course, as applicable to positivist accounts as to any other narrative. The historian's framework, vocabulary, objectives, and lens will shape the history presented. ${ }^{26}$ The process is shot through with complexities and contradictions of its own. In particular, Koskenniemi directs our gaze to the pitfalls of imagining that our concerns are those of the historical era we are exploring. ${ }^{27}$ For this reason, Koskenniemi argues, it is all the more important to adopt a contextual reading of international law, examining the actual purpose of the writings, the concerns of the period, and the political, economic and cultural influences operating on the actors at the time. ${ }^{28}$ But all the while, not, in the process, losing sight of the critical approaches that explore the implications of those contexts, the role law played as a facilitator of commercial and political objectives, and the unexpected narratives that can emerge through this process. ${ }^{29}$ What is clear, even at this point in the enquiry, is that, despite claims to the contrary, international law itself is not neutral nor is it the purveyor of objective, universal truths. ${ }^{30}$ What

\footnotetext{
${ }^{24}$ See the discussion in Koskenniemi, above n 12, 70-5.

${ }^{25}$ See the discussion of this tendency in Anghie, above n 8, 109.

${ }^{26}$ Martii Koskenniemi, 'Histories of International Law: Significance and Problems for a Critical View' (2013) 27 Temple ICLJ 215, 230.

${ }^{27}$ Ibid, 226-7. As an example, Koskenniemi describes current tendencies to describe Vitoria as 'an activist in human rights' although he advocated the burning of heretics.

${ }^{28}$ Ibid, 226-9.

${ }^{29}$ Ibid, 229-32, 238-40.

${ }^{30}$ See the discussion in Pahuja, above n 3; see also Anghie, above n 8; see also Jason A Beckett, 'Rebel
} 
that means for international investment law and its appeals to the universal is the question for the next section of this article.

\section{Historical Perspectives on International Investment Law}

I have written elsewhere on the origins of international investment law. ${ }^{31}$ Here, although I draw on aspects of that work, my focus is on the specific application of those theories to the question of universality and its use within international investment law, both past and present. These stories are, of course, intertwined with the emergence of international law more generally. The translation of European inter-state rules and principles into international law is also the story of the global expansion of European trading and investment activities from the seventeenth to early twentieth centuries. ${ }^{32}$ The practices and principles developed during this era were designed to enable and protect those European commercial and political interests-and a core part of that process was the repeated asserting of the universal nature of rules of international trade and investment law.

\subsection{Cementing Conceptualisations}

The assertion of legal authority regarding property, investments and trading rights in this early period was as chaotic and improvised as any other setting within the activities of empire. ${ }^{33}$ As mentioned above, the imperial context not only entailed inconsistent levels of territorial control, but also constituted tumultuous spaces for legal contestation and the dissemination of international law. Against this background, disputes over property took on an added significance that went well beyond their immediate local context. ${ }^{34}$ At a profound level, then, seemingly disparate individual skirmishes and cases in local and imperial fora

\footnotetext{
Without a Cause? Martti Koskenniemi and the Critical Legal Project' (2006) 7 German LJ 1045, $1047-8$.

${ }^{31}$ Kate Miles, The Origins of International Investment Law: Empire, Environment and the Safeguarding of Capital (2013).

${ }^{32}$ M Sornarajah, The International Law on Foreign Investment (3rd edn, 2010) 19-21; Charles Lipson, Standing Guard: Protecting Foreign Capital in the Nineteenth and Twentieth Centuries (1985) 12-21.

${ }^{33}$ See the discussion of the improvised nature of legal arrangements in an imperial context in McHugh, above n 20, 234-6.

${ }^{34}$ Benton, above n 8, 10-11, 22-3.
} 
contributed to that contest for jurisdictional control, retention of power, and, perhaps, most significantly, for the fundamental conceptualisations that would go on to form prevailing legal, commercial and political approaches in the colonial context. ${ }^{35}$ This was simultaneously also to play a crucial role in the emergence of international law as a universally applied legal regime. ${ }^{36}$

The establishing and cementing of multi-layered authority of this nature involved numerous parallel strategies. And with respect to the emergence of foreign investment protection law, the methods were varied. On one level, this entailed the construction of legal doctrine and its assertion as existing law, the conclusion of agreements such as 'friendship, navigation and commerce' treaties, and the establishment of areas of extraterritorial jurisdiction. Commercially, it included the pursuit of concessions and the securing of trading posts. Politically, the spectrum ranged from the use of diplomatic pressure to military intervention, the colonial annexation of territory, and the imposition of capitulation treaties. ${ }^{37}$ These devices are, of course, all inter-related and the categorisation into legal, commercial and political is somewhat artificial. In essence, the sum of these individual practices was an interactive process of feeding into each other, with interests and objectives shaping the law and the legal rules, in turn, shaping conceptualisations. Interestingly, it was the repetition of these modes of interaction that not only reinforced expectations of conduct, but would also contribute to the development of customary international law. ${ }^{38}$

In fact, the emergence of modern international rules on trade and investment out of such practices was very much a dual process of assertion and creation. Despite customary international law on investor protection not yet being fully formed or settled, capital-exporting states claimed it as such and firmly asserted the legitimacy of those particular practices within international law. ${ }^{39}$ The impact of those reiterated assertions would be far-reaching. Indeed, with an appreciation of the importance of each of these strategies to the overall process, it can be

\footnotetext{
35 Ibid.

${ }^{36}$ Ibid.

${ }^{37}$ Sornarajah, above n 32, 19-21, 180-1; Lipson, above n 32, 12-21; Nico Schrijver, Sovereignty Over Natural Resources: Balancing Rights and Duties (1997) 173-5.

${ }^{38}$ Benton, above n 8, 25-7.

${ }^{39}$ See, for example, the disputes surrounding The United States and Paraguay Navigation Company Claim, extracted in J B Moore, A History and Digest of the International Arbitrations to which the United States has been a Party, vol 2 (1898) 1485, 1865; Britain (Finlay) v Greece (1846) 39 BFSP 410; Delagoa Bay Railroad Arbitration, extracted in Moore, above n 39, 1865; Britain $v$ The Kingdom of the Two Sicilies (1839-1840) 28 BFSP 1163-242; Venezuelan Arbitrations, extracted in Jackson H Ralston, Venezuelan Arbitrations of 1903 (1904).
} 
seen that the repeated assertions of host state obligations, and the appeals to the legitimacy of actions taken to enforce them, contributed so significantly to the solidifying of those assertions as universally applicable rules of international law. Within both the formal colonial context and that of 'informal empire' in the eighteenth and nineteenth centuries, this reiteration and consolidation took place in multiple sites of contestation. Within formal colonial frameworks, uneasy pluralities of political and legal authority operated in incremental ways so as to support institutional resolutions. Legal conflicts over property embodied contests of authority on a smaller, more localised, scale, which, in affirming the legitimacy of extraterritoriality and principles of protection for foreigners' property, reinforced regimes at a wider level. ${ }^{40}$ Outside that formal context, several doctrines of international law, contested incidents, and cases stand out in particular, such as, the doctrine of diplomatic protection of alien property and the cases that applied it, ${ }^{41}$ the nineteenth century rejection of the Calvo Doctrine, the Soviet Union challenge following World War I, and the Mexican expropriations of the 1930s. Before discussing these matters, however, there is an even earlier influence on the form of modern international investment law that ultimately emerged-the major trading companies of the seventeenth century.

\subsection{The Dutch East India Company, Grotius and International Law}

Seventeenth century merging of imperialist and commercial objectives marshalled in the entirely new entity that was the trading company imbued with sovereign powers. This novel approach saw the founding of, for example, the Dutch East India Company (VOC), ${ }^{42}$ the English East India Company, and the French East India Company. ${ }^{43}$ It is well known that these companies not only pursued commercial interests, but also advanced the political goals of their home

\footnotetext{
$\overline{40}$ Benton, above n 8, 2-3, 17-27, 211-16.

${ }^{41}$ Such as the Delagoa Bay Railroad Arbitration, extracted in Moore, above n 39, 1865; Venezuelan Arbitrations of 1903, extracted in Jackson above n 29; Britain (Finlay) v Greece (1849-1850), 39 BFSP 410; Britain $v$ The Kingdom of the Two Sicilies (1839-1840), 28 BFSP 1163.

42 In Dutch, the Company's name was the Verenigde Oostindishe Compagnie, or 'the United East India Company', hence it being known as the VOC; see Die Staten General der Vereeniche Nederlanden, Octrooi van de, 20 March 1602 (Charter of the VOC, Granted by the States-General of the United Netherlands, 20 March 1602).

${ }^{43}$ Compagnie Française des Indes Orientales was founded in 1664, chartered by Louis XIV, 28 May 1664. With respect to the East India Company, see Charter Granted by Queen Elizabeth to the Governor and Company of Merchants of London, Trading into the East-Indies, 31 December 1600; Letters Patent Granted to the Governor and Company of Merchants of London, Trading into the
} 
states. To that end, they were granted authority to conduct military operations, establish trading posts, acquire territory, conclude treaties, found and govern settlements, and carry out judicial functions. ${ }^{44}$ What is, perhaps, not quite so well appreciated is the impact they had on international law. Empowering companies to operate on the international stage in this way clearly created a new type of legal actor and this in itself necessitated the design of new international legal doctrine. But it also generated the development of new international rules in a less obvious fashion, most notably in the collaboration of the VOC and Hugo Grotius.

Grotius has been, at times, described in the past as 'the father of international law. ${ }^{45}$ However, he was not an entirely disinterested theorist. Rather, Grotius had his objectives and intended audience firmly planted in the immediate concerns of the day and he was, at times, directly engaged by the VOC to devise legal arguments validating their activities and bolstering their claims to property and territory. ${ }^{46}$ Accordingly, founding treatises were written and core doctrines expounded that were, indeed, favourable for both state and Company. In particular, De Mare Liberum (freedom of the high seas) asserts that no state may claim exclusive rule over the sea. ${ }^{47}$ Together with De Jure Praede (the law of prize and booty), ${ }^{48}$ De Mare Liberum, which was originally chapter twelve of De Jure

East-Indies, 3 April 1661; The East India Company has also been known as the English East India Company and the British East India Company. To avoid confusion with other trading companies, I adopt the term 'English East India Company'. However, its formal name from 1600-1708 was the Governor and Company of Merchants of London, Trading into the East-Indies, and from 1708-1873, the United Company of Merchants of England Trading to the East Indies.

${ }^{44}$ M F Lindley, Acquisition and Government of Backward Territory in International Law (1926) 94. See also the discussion in Claudia Schnurmann, 'Wherever Profit Leads Us, to Every Sea and Shore...: the VOC, the WIC, and Dutch Methods of Globalization in the Seventeenth Century' (2003) 17 Renaissance Studies 474, 477-80; Janet McLean, 'The Transnational Corporation in History: Lessons for Today?' (2004) 79 Indiana LJ 363, 368-9.

${ }^{45}$ See, for example, Hamilton Vreeland, Hugo Grotius: Father of the Modern Science of International Law (1917).

${ }^{46}$ Letter of Jan ten Grootenhuys, merchant and VOC shareholder, younger brother of the VOC director Arent ten Grootenhuys, and liaison between Grotius and the VOC, 15 October 1604, commissioning the formal defence of Van Heemskerck's seizure of the Santa Catalina, translation in Hugo Grotius, Commentary on the Law of Prize and Booty (edn Liberty Fund, 2006; 1608) 545-7; see also Ileana M Porras, 'Constructing International Law in the East Indian Seas: Property, Sovereignty, Commerce and War in Hugo Grotius' De Iure Praede-The Law of Prize and Booty, or "On How to Distinguish Merchants from Pirates"” (2006) 31 Brooklyn JIL 741, 742-3, 744-7; Martine Julia van Ittersum, Profit and Principle: Hugo Grotius, Natural Rights Theories and the Rise of Dutch Power in the East Indies (1595-1615) (2006).

${ }^{47}$ Hugo Grotius, The Free Sea (edn Liberty Fund, 2004; 1609).

${ }^{48}$ Grotius, above n 46. Completed in 1608, Grotius' manuscript, De Jure Praede, remained 
Praede, was written against the backdrop of the Dutch conflicts with Portugal, Spain and England. In particular, they were designed to counter claims by these competitor nations to areas of the sea that would have led to the exclusion of the Dutch from valuable ocean trading routes and to justify military incursions into non-European territories to establish or protect commercial interests. It was also a means to thwart the purported trading monopolies of the Portuguese in the East Indies and assert a 'right to trade' approach of universal application, key statements of which include: ${ }^{49}$

1. Access to all nations is open to all, not merely by the permission but by the command of the law of nations.

$[\ldots]$

3. Neither the sea itself nor the right of navigation thereon can become the exclusive possession of a particular party, whether through seizure, through a papal grant, or through prescription (that is to say, custom).

4. The right to carry on trade with another nation cannot become the exclusive possession of a particular party, whether through seizure, through a papal grant, or through prescription (that is to say, custom).

More specifically, the propositions in these texts also verified the legality of the seizure by the VOC of a Portuguese ship, the Santa Catarina, and its tremendously valuable cargo: ${ }^{50}$

[T] he war which is being waged by the Dutch East India company against the Portuguese, the former owners of the captured vessel, is a just war; and the seizure of the prize in question was therefore entirely just [...]

unpublished until 1868, when it was first published in Latin, translated by H G Hamaker, then published in English in 1950.

${ }^{49}$ Grotius, above n 46, 300-1; see also Porras, above n 46, 802-4; Anghie, above n 1 . See also the discussion in April Carter, The Political Theory of Global Citizenship (2001) 28; Vincent C. Loth, 'Armed Incidents and Unpaid Bills: Anglo-Dutch Rivalry in the Banda Islands in the Seventeenth Century' (1995) 29 Modern Asian Studies 705, 718-20.

${ }^{50}$ Grotius, above n 46, 388; Porras, above n 46; Martine Julia van Ittersum, 'Hugo Grotius in Context: Van Heemskerck's Capture of the Santa Catarina and its Justification in De Jure Praedae' (1604-1606)' (2003) 31 Asian Journal of Social Science 511. 
Porras has argued that the construction of international legal doctrine in this way effectively treated the protection of commerce as a matter of national identity, the threat to which was a legitimate basis to wage war. ${ }^{51}$ Such an association enmeshed the private commercial interests of traders and foreign investors with those of the state in a particularly overt fashion and it established that fusion within the law itself.

This was at a formative stage in the development of international law and the theories devised could not have amounted, at the time, to little more than assertions of the law, in much the same way as a barrister in the modern context asserts the position of his or her client. Indeed, van Ittersum has gone so far as to say that Grotius' contemporaries would not have recognised nor agreed with his summation of the law. ${ }^{52}$ However, the propositions were presented as existing law and were treated as such by the states it suited to do so. This also had a profound impact on the direction international law would take both in general and as pertaining to the treatment of foreign investors. Reflecting Grotius' theories, that close alignment between the state and private commerce continued to find form in the translation of European trading and investment principles into universal rules of international investment law, most obviously in the nineteenth century development of the doctrine of diplomatic protection of alien property.

\subsection{Assertion, Challenge and Response in the Nineteenth and Twentieth Centuries}

The process of replacing the many and varied inter-nation legal regimes in existence in the seventeenth and eighteenth centuries with a universal system of international law based on European conceptualisations of property and private commerce was inarguably a complex and lengthy one. ${ }^{53}$ Aspects of this interactive process of challenge and response have been highlighted above, although, in the context of this article, it is a necessarily brief discussion. Exploring the perseverance of this contest into the nineteenth century, however, is also central to understanding objections to claims to universality in the twenty-first. Accordingly, I turn now to a critical period in which the enmeshed

\footnotetext{
${ }^{51}$ Porras, above n 46, 802-804.

52 Grotius, above n 46, see Van Ittersum's Introduction at, xviii.

${ }^{53}$ See Benton, above n 8, 10-11; Anghie, above n 8, 32-3, 115; Lipson, above n 32, 16, 20-1; Sornarajah, above n 32, 19.
} 
state and trader/investor of Grotius' theories reappeared as the doctrine of diplomatic protection and elicited the challenge that was the Calvo Doctrine.

\subsubsection{Diplomatic Protection and the Calvo Doctrine}

International rules on the protection of foreign investors and their property emerged in the nineteenth century within an area of law known as the diplomatic protection of aliens. ${ }^{54}$ This established an international minimum standard of treatment afforded to foreigners when abroad, a breach of which gave rise to a right of home state intervention. ${ }^{55}$ At its core, the doctrine articulated the notion that an injury done to a foreign national was an injury to their state and that this, in turn, entitled the state to respond on their national's behalf. ${ }^{56}$ It was, of course, in any literal sense, a conceit. But the doctrine not only reflected the protective responsibilities of a state to its citizens, it also fused the activities and interests of state and investor at a fundamental level within the law. Substantively, the international minimum standard encompassed a range of protections, including the prohibition on uncompensated expropriation of foreign-owned property. ${ }^{57}$ Following a breach of this nature, the aggrieved state could respond in a number of ways. It was entitled to do nothing at all, leaving the investor with no recourse, limit itself to diplomatic protest, or send in its warships. ${ }^{58}$ The particular course of action adopted largely depended on the wider political and commercial circumstances of the incident, but there is no doubt that the doctrine was, at times, used as grounds for political intervention and military incursion into the host state. ${ }^{59}$ What became known as 'gunboat diplomacy' was very much a part of the nineteenth century response strategy under the doctrine of diplomatic protection to interference with the interests of

\footnotetext{
${ }^{54}$ James Crawford, Brownlie's Principles of Public International Law (8th edn, 2012) 611.

${ }^{55}$ Edwin Borchard, The Diplomatic Protection of Citizens Abroad (1915) 25-29, 39; Clyde Eagleton, The Responsibility of States in International Law (1928) 3, 6, 22.

${ }^{56}$ Crawford, above n 54, 607; Sornarajah, above n 32, 18, 121. Building on the works of Grotius, Emmerich de Vattel expressed the theory in the eighteenth century in his influential text, The Law of Nations (1758) (translation) 136: "[w] hoever ill-treats a citizen injures the State, which must protect that citizen'.

${ }^{57}$ Lipson, above n 32, 53; Borchard, above n 55, 493-556; B A Wortley, Expropriation in Public International Law (1959) 33-5; Isi Foighel, Nationalization: A Study in the Protection of Alien Property in International Law (1957, reprinted 1982).

58 Borchard, above n 55, 439-56; Lipson, above n 32, 53; Wortley, above n 57, 58.

${ }^{59}$ Sornarajah, above n 32, 36-9; Schrijver, above n 37, 177-78.
} 
foreign investors. ${ }^{60}$ And, in this way, the harming of private commerce had again been constructed as a legal basis on which to justify warfare against other states.

Appeals to the doctrine and the international minimum standard can be seen throughout this period in diplomatic correspondence, ${ }^{61}$ arbitral awards and disputes, ${ }^{62}$ the writings of theorists, ${ }^{63}$ and the practice of states. ${ }^{64}$ For example, the assessment put forward by Borchard is fairly typical of the era: ${ }^{65}$

The establishment of the limit of rights which the state must grant the alien is the result of the operation of custom and treaty, and is supported by the right of protection of the alien's national state. This limit has been fixed along certain broad lines by treaties and international practice. It has secured to the alien a certain minimum of rights necessary to the enjoyment of life, liberty and property, and has so controlled the arbitrary action of the state.

[...]

International law is concerned not with the specific provisions of the municipal legislation of states in the matter of aliens, but with the establishment of a somewhat indefinite standard of treatment which the state cannot violate without incurring international responsibility. The state's liberty of action, therefore, is limited by the right of other states to be assured that a certain minimum in this respect will not be overstepped. A stipulation in treaties or municipal statutes to the effect that the state is not responsible

\footnotetext{
${ }^{60}$ Sornarajah, above n 33, 36-9; Miriam Hood, Gunboat Diplomacy 1895-1905: Great Power Pressure in Venezuela (1975) 189-92.

${ }^{61}$ See, for example, the correspondence between Secretary of State Baynard and Connery, 1 November 1887, Compilation of Reports of Committee on Foreign Relations, US Senate (1887) 751, 753: If a Government could set up its own municipal laws as the final test of its international rights and obligations, then the rules of international law would be but the shadow of a name, and would afford no protection either to states or to individuals. It has been constantly maintained, and also admitted by the Government of the United States, that a Government cannot appeal to its municipal regulations as an answer to demands for the fulfilment of international duties.

${ }^{62}$ See, for example, Britain (Finlay) v Greece (1849-1850) 39 BFSP 410; see also Correspondence concerning the Sicilian Sulphur Monopoly Case found at Britain $v$ The Kingdom of the Two Sicilies (1839-1840) 28 BFSP 1163.

${ }^{63}$ Borchard, above n 55, 39.

${ }^{64}$ See, for example, the actions of Germany and Britain in bombarding Caracas in 1902 in response to Venezuela's refusal to consent to international arbitration to settle claims arising out of civil unrest during 1898-1902.

${ }^{65}$ Borchard, above n 55, 39.
} 
to aliens to any greater extent to nationals has never prevented international claims where the minimum has been considered as violated, nor can the state's international obligations be avoided or reduced by provisions of municipal law, or by the fact that it violates the rights of its own citizens.

Contrary to the impression created by these writings, awards, and practices, however, this approach had not gone uncontested. ${ }^{66}$ It is particularly interesting to note that although the international minimum standard was asserted by capital-exporting states as an already existing, universally applicable rule of international law, this was, in fact, the time of its formation and it was not universally accepted as law. A competing rule had been devised and asserted by host states-the Calvo Doctrine. ${ }^{67}$ During the nineteenth century, Latin America had felt the full brunt of the doctrine of diplomatic protection, experiencing military incursions and bombardments from naval gunboats to protect alien property. There was also a sense amongst those states on the receiving end of such measures that the rule was periodically used as a premise for political interference and control. ${ }^{68}$ The development of the Calvo Doctrine was in direct response to this vulnerability. ${ }^{69}$ For that reason, its essence challenged the legality of the invocation of diplomatic protection and put forward the alternative proposition that: 'Aliens should be afforded no more than the same treatment as nationals and must limit themselves to filing claims in the local judicial system. ${ }^{70}$

Despite the vigorous lobbying from advocates such as Calvo and the diplomatic assertions of these propositions by Latin American states, the Calvo Doctrine did not find acceptance as a rule of international law. In an interesting dis-

\footnotetext{
${ }^{66}$ See the discussion in Schrijver, above n 37, 177-78; Kenneth J Vandevelde, 'A Brief History of International Investment Agreements' (2005) 12 UC Davis JILP 157, 159-60.

${ }^{67}$ One of the most prominent advocates of this position was the Argentinian lawyer and legal scholar Carlos Calvo, after whom the doctrine is named. He completed a six volume treatise, Le Droit International Théorique et Pratique, first published in 1868, and then five editions later, in its final form in 1896.

${ }^{68}$ Lipson, above n 32, 76-77; Schrijver, above n 37, 177-178; Donald Shea, The Calvo Clause: $A$ Problem of Inter-American and International Law and Diplomacy (1955) 5, 12-13, 30; Inter-American Bar Association, 'Report of the Third Conference of the Inter-American Bar Association, August 1944’ (1944) 26 J Comp Leg \& Int'l L 55, 57-8.

${ }^{69}$ Shea, above n 68, 5, 12-13; Lipson, above n 32, 76-7; Sornarajah, above n 32, 36-7, 120-3.

${ }^{70}$ Shea, above n 68; Frank Griffith Dawson \& Ivan L Head, International Law, National Tribunals, and the Rights of Aliens (1971) 15.
} 
cussion on the interactive nature of the emergence of international law, Arnulf Becker Lorca contends that the work of non-Western jurists such as Calvo: ${ }^{71}$

[I]nternalised the categories of classical international law, and ultimately used them in order to change, in the direction of equality, the rules of international law applicable vis-à-vis their polities. Their reinterpretation of the central elements of classical international law-positivism, absolute sovereignty and the standard of civilization-progressively achieved the inclusion of non-Western states within the regime of autonomy and equality. Thus, the doctrinal appropriation of semi-peripheral jurists transformed international law.

Becker Lorca suggests that Calvo's reinterpretation of the rules rendered his efforts a success and contributed to a form of universalising of international law through its appropriation and internalising by Calvo and other semi-peripheral jurists. $^{72}$ Becker Lorca's reading of the nineteenth century experience of international law does reflect the more nuanced and complex legal relationships that, in fact, inhabited imperial spaces in non-Western nations. Contrary to his assessment of Calvo's contribution, however, the attempt, in that case, was not at all successful in reshaping the law. Calvo appropriated and reinterpreted the rules of international law-but his reinterpretation did not influence the substance of the law on diplomatic protection of foreign-owned property. Rather, the Calvo Doctrine was resoundingly rejected by those in a position to confer legal authority on the propositions. And in rebuffing Calvo's attempt to participate in the shaping of international legal doctrine, the European, British and American legal communities responded to the challenge with the firm reassertion of their views of the law and the reiteration of its universality and neutrality, that is, the asserted 'traditional' position of the international minimum standard, with a particular emphasis on its universal application and assumptions that only through the impartiality of an international forum could aliens be assured of fair treatment in a dispute. ${ }^{73}$

${ }^{71}$ Arnulf Becker Lorca, 'Universal International Law: Nineteenth Century Histories of Imposition and Appropriation' (2010) 51 Harv ILJ 475, 475.

${ }^{72} \mathrm{Ibid}, 482,490-4,525-8$. In particular, Becker Lorca states at 526 that 'Calvo was remarkably successful'.

${ }^{73}$ Shea, above n 68, 20; see, for example, Borchard, above n 55, 39; see also Edward Borchard, 'The "Minimum Standard" of the Treatment of Aliens' (1940) 38 Mich LR 445, 452-461; see 
The development of the doctrine of diplomatic protection of alien property, the challenge embodied in the Calvo Doctrine, and the subsequent reassertion of the capital-exporting states' position as settled law was a process by which one perspective became entrenched as law through the repetitive rejection and quashing of alternatives. And when it is viewed through a long-range historical lens, it can be seen that this episode was not exceptional. Rather, it was part of an historical pattern of undulating assertions of power and challenges to power that have characterised not only the emergence of international investment law, but its evolution throughout the twentieth century and into the twenty-first-including current assertions of legitimacy through universality.

\subsubsection{Twentieth Century Challenges}

In turning to the twentieth century, my argument is that significant attempts were made at various points throughout this period to challenge the assertion that the international rules on foreign investment protection were well-settled. These included the early twentieth century agrarian reforms of Mexico and the Soviet Union, postcolonial nationalisations, and the founding of the New International Economic Order (NIEO). Again, in my view, these conceptual 'rebellions' should not be considered in isolation, but, rather, as forming part of concerted host state resistance to the prevailing system, emerging and re-emerging in an interactive process with capital-exporting states. And on each occasion, these challenges were met with the reassertion of capital-exporting states' stance as universal.

Such challenges manifested in the widespread land seizures launched across the Soviet Union, Hungary, Poland, and other Eastern European states at the end of World War I and by Mexico in the 1930s. ${ }^{74}$ It was claimed that as the seizures had taken place within general programmes of social and economic reform, those public interest objectives altered their character and classification. That context, it was argued, needed to be taken into account and required recognition within

also Institute of International Law, Regulations Respecting the Responsibility of States by Reason of Damages Suffered by Aliens in Case of Riot, Insurrection or Civil War: Recommendation, Session of Neuchatel, 10 September 1900: 'The Institute of International Law recommends that states should refrain from inserting in treaties clauses of reciprocal irresponsibility. It thinks that such clauses are wrong in excusing states from the performance of their duty to protect their nationals abroad and their duty to protect foreigners within their own territory'.

${ }^{74}$ Lipson, above n 32, 65-70, 77; Josef L Kunz, 'The Mexican Expropriations' (1940) 5:1 NYU School of Law Contemporary Pamphlets Series 25; John H Herz, 'Expropriation of Foreign Property' (1941) 35 AJIL 243, 252, 258-9. 
the law through the creation of a new category of taking-'nationalisation' rather than confiscation or expropriation. ${ }^{75}$

As a proposition, it was, perhaps unsurprisingly, rejected by home states, their investor nationals, arbitral tribunals, and legal commentators. ${ }^{76}$ In essence, the protests reiterated that the rules were clear and universal and could not be determined or modified by reference to the domestic law, policy, or social conditions of the host state. Such responses were then taken as evidence of the reaffirmation of the pre-war rules. ${ }^{77}$ Crucially, however, the actions of the host states were not considered as possessing a norm-creating character and did not constitute law-making 'practice of states', unlike those of the home states.

Considered by whom? A significant question. The importance of the identity of those empowered to do the 'considering' and the bestowing of legal authority on one proposition over another should not be underestimated. It was, of course, a self-appointed authority derived from the repetitive nineteenth century assertions of capital-exporting states. And, in much the same way as the validity of the Calvo Doctrine had been dismissed in the nineteenth century, so too were these early twentieth century attempts to participate in the development of the rules of international investment law. Had the rules been reshaped to take account of the perspective of host states, this could, perhaps, have imbued them with a truly universal quality, representative of a blending of positions. The opportunity, however, was not taken and, in the face of such a strident challenge to the legitimacy of the prevailing system, hollow incantations emphasising the universal application of the rules were again held out instead.

The dynamics were repeated decades later during and following the process of decolonisation. What should have been a period of meaningful participation and universalisation of international law as well as prosperity for postcolonial states, implementing policies to rebuild their economies and further their own interests, in many cases, became a source of disillusionment. ${ }^{78}$ In seeking to reclaim

${ }^{75}$ Kunz, above n 74, 26-27; Nicholas R Doman, 'Postwar Nationalization of Foreign Property in Europe' (1948) 48 Col LR 1125.

${ }^{76}$ Borchard, above n 73; Kunz, above n 74, 9-16; International Law Association, Report of the Protection of Private Property Committee (1926); Harvard Research in International Law, 'Responsibility of States' (1929) 23 AJIL Supp 133, Art 2.

77 Kunz, above n 74, 9-16; ILA, above n 76; Borchard, above n 73; Alwyn V Freeman, 'Recent Aspects of the Calvo Doctrine and the Challenge of International Law' (1946) 40 AJIL 121.

${ }^{78}$ Karen Mickelson, 'Rhetoric and Rage: Third World Voices in International Legal Discourse' (1997-1998) 16 Wisconsin ILJ 353, 362; Benjamin J. Richardson, 'Environmental Law in Postcolonial Societies: Straddling the Local-Global Institutional Spectrum' (2000) 11 Colorado JIELP 1, 2 . 
control over essential natural resources, newly independent states found themselves facing investor claims as a result of attempts to revisit concession contracts or to nationalise operations central to the economy. ${ }^{79}$ The response to this new form of political risk to investments made under colonial regimes was twofold-a reassertion of the traditional position through arbitral jurisprudence, interpreting principles in an overly supportive fashion and creating new legal doctrine; and the construction of new international regimes for investor protection.

Presented with arguments that postcolonial states were free to reassess concession contracts granted during colonial administration, a series of arbitral tribunals preferred the reasoning of capital-exporting states and their investor nationals and adopted a newly constructed doctrine, the internationalised contract', and a selective use of the acquired rights doctrine. ${ }^{80}$ In a novel move, it was argued that the governing law of the concession contract was the 'international law of contracts' or that the concession contract constituted a form of economic development agreement or 'quasi-treaty', to which applying the law of the host state would be inappropriate. ${ }^{81}$ And this approach was then also tied in with a particular application of the rules on acquired rights.

Traditionally, acquired rights held by foreign nationals are not absolute. They are granted by the host state and, correspondingly, can also be withdrawn. ${ }^{82}$ However, the reasoning put forward in support of concession holders ran along the lines that all states are subject to the rules of international law and the transition from colonial administered territory to independent state did not alter that basic condition. ${ }^{83}$ The newly independent state had assumed the rights and

\footnotetext{
${ }^{79}$ See, for example, the following notable disputes Petroleum Development Ltd $v$ The Sheikh of Abu Dhabi (1951) 18 ILR 144; Anglo-Iranian Oil Co (UK v Iran), ICJ Reports 1952 p 93; Ruler of Qatar v International Marine Oil Co (1953) 20 ILR 534; Texaco Overseas Petroleum Co \& California Asiatic Oil Co v Government of the Libyan Arab Republic (1975) 53 ILR 389; see also the discussion in R B Lillich, 'The Diplomatic Protection of Nationals Abroad: An Elementary Principle of International Law Under Attack' (1975) 69 AJIL 359; Francesco Francioni, 'Compensation for Nationalisation and Foreign Property: The Borderland Between Law and Equity' (1975) 24 ICLQ 255, 260-2.

${ }^{80}$ See the authorities referred to above $n 79$.

${ }^{81}$ For a contemporary discussion of the rationale for the doctrine of the 'internationalised contract', see Lord Arnold McNair, 'The General Principles of Law Recognized by Civilised Nations' (1957) 33 BYIL 1, 4; see, for a critique of this approach, Anghie, above n 8, 226-35; see, for example, the reasoning in Petroleum Development Ltd v. The Sheikh of Abu Dhabi, above n 79, 144, 149; see also Ruler of Qatar v International Marine Oil Co, above $\mathrm{n} 79$.

${ }^{82}$ Crawford, above n 54, 628-9.

${ }^{83}$ See, for example, the views expressed in Philip C Jessup, 'Non-Universal International Law' (1973) 12 Col JTL 415; see also the discussion in Matthew Craven, The Decolonisation of International Law: State Succession and the Law of Treaties (2007) 84-6.
} 
obligations of the former entity and that included any acquired rights held by foreign investors. ${ }^{84}$ This was interpreted to mean that postcolonial states were required to comply with the conditions of contracts entered into whilst under colonial administration, effectively placing the rights of the investor before the sovereign rights of the new state to review those acquired rights. ${ }^{85}$ It was an interpretation that validated the assertion of non-retractable concession rights, one described in Brownlie as 'unsatisfactory'. ${ }^{86}$ Essentially, the approach taken in cases such as Petroleum Development Ltd $v$ The Sheikh of Abu Dhabi, ${ }^{87}$ Ruler of Qatar v International Marine Oil Co, ${ }^{88}$ and Texaco Overseas Petroleum Co $\mathcal{E}$ California Asiatic Oil Co $v$ The Government of the Libyan Arab Republic ${ }^{89}$ was a form of 'arbitral-law-making', preferring one set of propositions over another, emphasising the well-established and universal nature of the rules, not to be modified to take account of the new postcolonial setting-but which were, in fact, given a creative interpretation, modifying their meaning and application to support the position asserted by investors and their home states.

Re-emergent challenges to investment rules continued during this period with an increasing number of postcolonial nationalisations and the more general calls for reforms to international economic frameworks that would go on to form the movement embodied in the NIEO. ${ }^{90}$ Echoing the nineteenth century attempts to reshape investment rules through the Calvo Doctrine, the NIEO proposed modified rules that better represented the interests of postcolonial and capital-importing states. ${ }^{91}$ In particular, the asserted rules included the principle of permanent sovereignty over natural resources, an 'appropriate' compensation standard or, in some instances, compensation assessed under national laws, and

\footnotetext{
${ }^{84}$ Anghie, above n 8, 213-14.

${ }^{85}$ Ibid, 211-16; see also the discussion in C G Weeramantry, Nauru: Environmental Damage Under International Trusteeship (1992) 307-12.

${ }^{86}$ Crawford, above n 54, 628-9.

${ }^{87}$ Petroleum Development Ltd $v$ The Sheikh of Abu Dhabi, above n 79.

${ }^{88}$ Ruler of Qatar $v$ International Marine Oil Co, above $\mathrm{n} 79$.

${ }^{89}$ Texaco Overseas Petroleum Co \& California Asiatic Oil Co v Government of the Libyan Arab Republic, above $\mathrm{n} 79$.

${ }^{90}$ Jagdish N Bhagwati, 'Introduction', in Jagdish N Bhagwati (ed), The New International Economic Order (1977) 1.

${ }^{91}$ Anghie, above n 8, 235, 312-13; Burns H Weston, 'The Charter of Economic Rights and Duties of States and the Deprivation of Foreign-Owned Wealth' (1981) 75 AJIL 437, 437-9; James Thuo Gathii, 'Third World Approaches to International Economic Governance', in Richard Falk, Balakrishnan Rajagopal and Jacqueline Stevens (eds), International Law and the Third World: Reshaping Justice (2008) 255.
} 
domestic law as the applicable law determining investment disputes. ${ }^{92}$ The response to these challenges was to dismiss them as 'politicising' investment disputes and, again, to reassert the traditional. But in a new shape that sought to develop a more systematic approach to ensuring the universal nature of investor protection - the pursuit of bilateral investment treaties and the creation of the International Centre for the Settlement of Investment Disputes (ICSID). ${ }^{93}$

The creation of ICSID within the auspices of the World Bank was set against a particularly charged political backdrop, emerging out of an impasse in attempts to conclude a multilateral treaty on investor protection. Capital-exporting states had seen a multilateral treaty as the answer to the political risk and legal uncertainty following decolonisation, but failed to secure the agreement of host states to the high-level substantive investment protection measures proposed. ${ }^{94}$ It is, perhaps, unsurprising that we again see appeals to the universal and the neutral emerging in the face of such strident resistance and challenge to the legitimacy of the system as a whole. Emphasising the need for 'depoliticisation' of investment disputes and pointing to the neutrality of international arbitration, the General Counsel of the World Bank, Aron Broches, proposed the creation of an international dispute settlement forum as distinct from the substantive standards. ${ }^{95}$ The assertion that only an international setting could be relied upon to apply universal rules and ensure a neutral, depoliticised, and fair hearing for a foreign investor was quite explicit. In this regard, it is interesting to note the express association between investor-state arbitration and the rule of law right at the development of the mechanism: ${ }^{96}$

But I have no doubt that [ICSID's] adoption would constitute a significant step forward toward the establishment of the Rule of Law in international investment.

\footnotetext{
${ }^{92}$ Declaration on Permanent Sovereignty over Natural Resources, GA Res 1803 (XVII) (1962) 15; Declaration on the Establishment of a New International Economic Order, GA Res 3201(S-VI) (1974), para 4.

${ }^{93}$ Convention on the Settlement of Investment Disputes between States and Nationals of Other States, 18 March 1965, 575 UNTS 159; Anghie, above n 8, 236-7; see the discussion in Ibironke T Odumosu, 'The Law and Politics of Engaging Resistance in Investment Dispute Settlement' (2007) 26 Penn State ILR 251, 255.

${ }^{94}$ Newcombe \& Paradell, above n 5, 19-20; Gus van Harten, Investment Treaty Arbitration and Public Law (2007) 19-23.

${ }^{95}$ Shihata, above n 5; Aron Broches, 'Settlement of Investment Disputes: 1963 Address to the World Conference on World Peace through Law', in Aron Broches, Selected Essays: World Bank, ICSID, and Other Subjects of Public and Private International Law (1995) 161.

${ }^{96}$ Ibid, 163.
} 
Indeed, depoliticisation was the rationale for ICSID and held up as a core basis for the legitimacy of the novel system it introduced-investor-state arbitration. In this way, the rhetoric in linking universal rules, international arbitration, 'fairness', and 'the rule of law' was perpetuated, as was the practice of rejecting legal views with which capital-exporting states disagreed as not neutral, universal, objective, or in accordance with the rule of law.

Furthermore, despite decrying the need for neutrality and depoliticisation, the politics were quite clear. Because of ICSID's original purpose and the circumstances out of which it emerged, this international investment legal framework is, in fact, profoundly political, but in a form that benefits foreign investors. In this regard, the comments of Broches following the conclusion of the text for the ICSID Convention are particularly illuminating: ${ }^{97}$

\begin{abstract}
Quite obviously any agreement dealing with problems of foreign investment is politically sensitive. Attempts in this area made in the United Nations had never reached the take-off point because of political opposition. It was our hope that in the more businesslike atmosphere of the governing bodies of the Bank it would be possible to discuss the problem on the merits and without extremes of ideological debate, especially because, whatever the variety of views among the Bank's membership on social and economic problems, it does not include the Soviet Union and the other countries of the Eastern bloc.
\end{abstract}

In the discourse surrounding the establishing of ICSID, its legitimacy was presented as self-evident. Framing the position of host states in a derogatory way as 'political' rather than legal and emphasising the 'business-like' objectivity of capital-exporting states and of the World Bank, together with assertions that it would enhance the rule of law, inherently cast ICSID as a legitimate construct. The corresponding inference being that reticence towards international arbitration and the ICSID framework was suspect and illegitimate. It claimed universality and inclusiveness, while, at the same, excluded objecting states and divergent perspectives from the sphere of legitimacy. It was out of this politico-legal process of assertion and response that the modern architecture for international investment dispute settlement was constructed. And at each crucial juncture in which

\footnotetext{
${ }^{97}$ Aron Broches, 'Development of International Law by the International Bank for Reconstruction and Development' (1965) 59 ASIL Proc 33, 35.
} 
space could have been made for a form of international investment law that better accommodated the host state position, it was instead rejected, ironically, amid claims to universality.

\subsection{A Concluding Note on the Twenty-First Century}

At the close of this paper, I want simply to draw your attention to a trend in recent years to frame investor-state arbitration as a component of 'global administrative law'. With increasing prevalence, twenty-first century advocates of the prevailing system of high-level investment protection and international arbitration have been pointing to its universality and objectivity. ${ }^{98}$ There is also currently a tendency to describe investor-state arbitration as the epitome of the rule of law, good governance, and neutrality and to ascribe to this phenomenon the term 'global administrative law.' 99

Global administrative law is said to comprise the rules, practices, and institutions that operate at an international level and entails the examination of those forms of regulation and governance. ${ }^{100}$ It is largely concerned with procedural matters such as transparency, public participation, and review that implicate questions of legitimacy and governance models. Investor-state arbitration is, indeed, part of that web of administrative functions and entities at both domestic and international levels that have been performed for decades. ${ }^{101}$ Fundamentally, this is nothing new. The nature of these administrative activities in the twentyfirst century does not constitute a radical departure from previous decades. So, to assign a particular label to these series of interactions and institutions as 'global administrative law' has implications that go beyond the fact of these occurrences. Susan Marks has described this as the 'power of naming.'102 Attaching a label and

\footnotetext{
${ }_{98}$ Paulsson, above n 5; Yackee, above n 5, 1551-2, 1570; Weiler \& Wälde, above n 5; Jan Paulsson, The Idea of Arbitration (2013) 189, 259, 291.

${ }^{99}$ See, for example, Schill, above n 6; Weiler \& Wälde, above n 5; Kingsbury and Schill, above n 6; Kalderimis, above n 6; Kotuby, above n 6; Postiga, above n 6; Gus Van Harten \& Martin Loughlin, 'Investment Treaty Arbitration as a Species of Global Administrative Law' (2006) 17 EJIL 121.

${ }^{100}$ Benedict Kingsbury, Nico Krisch \& Richard B Stewart, 'The Emergence of Global Administrative Law' (2005) 68 L \& Contemp Probs 15; Daniel C Esty, 'Good Governance at the Supranational Scale: Globalizing Administrative Law’ (2006) 115 Yale LJ 1490; Benedict Kingsbury, Nico Krisch, Richard B Stewart \& Jonathan B Wiener, 'Global Governance as Administration-National and Transnational Approaches to Global Administrative Law' (2005) 68 L \& Contemp Probs 1; see also Ming-Sung Kuo, 'Taming Governance with Legality? Critical Reflections upon Global Administrative Law as Small-C Global Constitutionalism' (2011) 44 NYUJILP 55.

${ }^{101}$ Van Harten \& Loughlin, above n. 99.

${ }^{102}$ Susan Marks, 'Naming Global Administrative Law' (2005) 37 NYUJILP 995.
} 
constructing a new conceptual framework through which to view familiar entities changes what is being observed. ${ }^{103}$ The global administrative law project, as it is termed, is problematic on this and other levels. ${ }^{104}$ As Marks points out: ${ }^{105}$

\begin{abstract}
In his book On the Name, Jacques Derrida asks what happens when one gives a name: does one give then? One does not offer a thing, one delivers nothing, and still something comes to be. Precisely a new noun phrase like global administrative law seems to create a thing. It seems to bring an object into being, with a solidity and even a monumentality that risks putting in the shade disputes over process, agency, and orientation.
\end{abstract}

There has certainly been an inordinate amount of excitement generated by this 'new thing', yet not 'new thing', embodied in global administrative law. But what precisely is it that we now see? And to what end?

In the context of investor-state arbitration, the issue, as I see it, is whether this new global administrative law label contributes to a legitimising of the system, simply by association with the terminology, just at the time when that system is again facing challenges of legitimacy. ${ }^{106}$ In other words, it is very difficult to maintain that there are problems with a system of dispute resolution that is framed as, in itself, being the embodiment of the rule of law, good governance, and

\footnotetext{
${ }^{103}$ Ibid.

${ }^{104}$ New York University, School of Law, established a Global Administrative Law Research Project, out of which the 'global administrative law' emerged. See the project website at $<$ http://www.iilj.org/gal/> [accessed 25 August 2014]. See also the critique that the conceptualisation of global administrative law as procedural disconnects the rules and activities of international entities from substantive rules and the human rights, environmental, and economic needs of developing states, in B S Chimni, 'Co-Option and Resistance: Two Faces of Global Administrative Law' (2005) 37 NYUJILP 799.

${ }^{105}$ Marks, above n 102, 996.

${ }^{106}$ For a discussion on the concern of the legitimacy of investor-state arbitration, see Susan D Franck, 'The Legitimacy Crisis in Investment Law and Arbitration: Privatising Public International Law through Inconsistent Decisions' (2005) 73 Fordham LR 1521; see generally, Michael Waibel et al (eds), The Backlash against Investment Arbitration: Perceptions and Reality (2010); see the critique on the system in, for example, Philippe Sands, 'Searching for Balance: Concluding Remarks; Colloquium on Regulatory Expropriations in International Law' (2002) 11 NYUELJ 198; and also in M Sornarajah, 'A Coming Crisis: Expansionary Trends in Investment Treaty Arbitration', in Karl P Sauvant (ed) Appeals Mechanism in International Investment Disputes (2008) 39; and in Kyla Tienhaara, 'What You Don't Know Can Hurt You: Investor-State Disputes and the Protection of the Environment in Developing Countries' (2006) 6 Global Environmental Politics 73 .
} 
neutrality. The appeals to universality contained within labelling investor-state arbitration as global administrative law are couched within familiar terms-a neutral forum, safely removed from the 'politicised' environment of the host state, in which universal rules can be applied, reviewing the conduct of the state against objective standards.

The framing of investor-state arbitration in this way is rather reminiscent of the rationale for asserting the need for the international minimum standard in the nineteenth century and the creation of ICSID in the twentieth. And so we see once again, where there is a challenge to the traditional mode of investor protection, we find a reassertion of it. This time, in the form of situating investor-state arbitration within a global administrative law framework. Being able to claim 'universal', 'neutral' and 'objective' as traits does enhance the legitimacy of a system and the claims of investor-state arbitration to these attributes are not without a purpose. Indeed, I am very much of the view that it represents yet another manifestation of the patterns that have been around for a long time. Patterns of assertions, challenge, and reassertion of the traditional. Different forms; same dynamic. Again, in the name of upholding a universal system. 